\title{
Impact Analysis of Replacing Business Tax with Value-added Tax on Water Conservancy Project Cost
}

\author{
Yongjia SONG, Lin YUAN* \\ North China University of Water Resources and Hydropower \\ Zhengzhou, China \\ e-mail: syj55556666@163.com,931476610@qq.com*
}

\author{
Di WU \\ Henan Construction Vocational and Technical College \\ Zhengzhou, China \\ e-mail: 43839287@qq.com
}

\author{
Chao BA \\ Runan Construction Group Co., Ltd. Henan \\ Zhengzhou, China \\ e-mail: bate811010@126.com
}

\begin{abstract}
Nine representative examples of water conservancy projects are selected, and the cost changes of water conservancy project are calculated by combining the cost adjustment method of replacing business tax with value-added tax on water conservancy project. At the same time, analyzing the reason for the change in cost is based on the resulting measured data. The results show that after the implementation of VAT of water conservancy project, the project cost show a slight downward trend. The proportion of labor cost, material cost and mechanical use fee is the main reason for changes in Water Conservancy project cost.
\end{abstract}

Keywords-water conservancy project;cost;business tax; value-added tax; change;analysis

\section{INTRODUCTION}

Approved by the State Council, on the basis of pilot projects of replace business tax with value-added tax in some industries in the previous period, the Ministry of Finance and the State Administration of Taxation promulgated the Notice on Pilot Opening of replacing business tax with value-added tax (Finance [2016] No. 36), demanding units and individuals that sell services, intangible assets or immovable property within the People's Republic of China shall be value-added taxpayers, who shall pay VAT according to this method and do not pay business tax. The scheme will be implemented on May 1, 2016. Putting forward to replacing business tax with value-added tax avoids the duplication of taxation prevailing in the construction industry, reduces the tax burden, boosts the vitality of enterprises and promotes the industry toward a more positive and healthy direction. With replacing business tax with value-added tax gradually implemented in the construction industry, a series of policy documents were promulgated by the state. Construction tax policy is gradually clear. The business tax will be withdrawn from the historical stage and the VAT system will be more standardized. The Ministry of Water Resources promulgated the cost adjustment method of replacing business tax with value-added tax on water conservancy project, and the water conservancy project accordingly promoted replacing business tax with value-added tax[1].

Jing-Xin Liu[2]analyzed the tax balance point. The results of his research show that the impact of replacing business tax with value-added tax on the conservancy cost is about $\pm 3 \%$ through the model analysis. Yu-Qiang $\mathrm{Hu}[1]$ made an overall judgment, which provided an important theory and practice for replacing business tax with valueadded tax in the water conservancy industry. The research results show that after replacing business tax with valueadded tax, the investment in water conservancy project and the tax burden have been theoretically reduced.

By selecting typical cases of replacing business tax with value-added tax on the water conservancy project to calculate and analyze results, it will provide data reference for future cost compilation and management of water conservancy industry.

\section{Water CONSERVANCy PROJECT CALCULATION AND ANALYSIS METHOD}

This paper selects 9 typical cases of water conservancy projects, including three hydro-junctions, three water diversion projects, three river projects, through the Yitou software to calculate and analyze the changes in the cost data before and after replacing business tax with value-added tax.

\section{A. Tax Rates And Tax Base Adjustments}

The general method of project cost tax payable refers to the current output tax deduction of current input tax balance[3], the tax payable calculation formula is:

Tax payable $=$ current output tax - current input tax

Output tax refers to the taxable acts of taxpayer in accordance with business tax and VAT rates calculated and collected[3], output tax calculation formula is:

$$
\text { Output tax }=\text { sales } \times \text { tax rate }
$$


Before the implementation of VAT, the tax includes business tax, city maintenance and construction tax, education surcharge and local education surcharge. The tax base is tax-free. According to the location of the project, the consolidated tax rates take $3.48 \%, 3.41 \%$ and $3.28 \%$ respectively. After replacing business tax with value-added tax, taxes will only calculate VAT on output tax, and the tax rate will be adjusted uniformly to $11 \%$. However, urban maintenance and construction tax, education surcharge and local education will be added to the enterprise management fee. Direct costs (including: labor costs, materials costs, construction machinery use fees and other direct costs), indirect costs, profits, materials reserve make up the full in accordance with excluding VAT input tax basis for calculating VAT.

\section{B. Basic Unit Price Adjustment}

(1) The labor budget price is the same as the current calculation standard[4].

(2) Material budget price $=$ (original price of material + transportation fees) $\times(1+$ purchase and storage rate $)+$ transportation insurance

Original price of the material, transportation fees, transport insurance and purchase and insurance premiums were calculated separately at the price excluding VAT input tax. The purchasing and insurance premiums are multiplied by the adjustment factor of 1.1 according to the current standard [4].

In the early stage preparation of budget estimates(estimation) documents, the material prices should be information prices excluding tax or market research taxfree prices. The transitional phase of the material prices can be adjusted by dividing the tax-inclusive price by the adjustment factor into a tax-excluded prices. The adjustment methods are as follows: (1)The main material divided by 1.17 adjustment factor. Secondary material divided by 1.03 . Purchased sand, stone, soil material temporarily divided by 1.02 adjustment factor. (2)Divide the freight and miscellaneous calculated by the original amount standard by the adjustment coefficient of 1.03, divide the freight and miscellaneous by the rate by the adjustment coefficient of $1.10[4]$.

The wind, water and electricity budget price and machinery stage at fee are calculated according to the basic price of the adjusted construction machinery stage at fee and excluding the VAT input tax, of which the basic electricity price in the grid power supply price should exclude the VAT input tax[4].

(3) Construction mechanical use fee shall be calculated on the basis of the adjusted fee of construction machinery stage at fee quota and the basic price excluding VAT. Depreciation of construction machinery stage at fee quota divided by the 1.15 adjustment factor, repair and replacement equipment costs divided by 1.11 adjustment factor, installation and removal costs unchanged. Entry-driving machine and other construction machinery purchased by the construction unit, equipment costs separate items of construction machinery, machinery stage at fee not include depreciation fee and the equipment fee shall be divided by the adjustment factor of 1.17 [4].

\section{Construction Quota Adjustment}

Structural details of hydraulic conservancy project indicators temporarily are not adjusted. Other materials costs, other machinery costs and sporadic material fee rates which are expressed by the form of rates $(\%)$ in construction quotas, installation quotas are not adjusted. Labor costs represented by the rate form $(\%)$ is fixed, the material fee rate divided by 1.03 adjustment factor, the rate of mechanical fee divided by 1.10 adjustment factor, device material fee Rate divided by 1.17 adjustment factor. Calculate the base constant, is still a VAT with equipment fee[4].

\section{WATER CONSERVANCY PROJECT CALCUlation CONCLUSION AND ANALYSIS}

\section{A. Impact of Replacing Business Tax with Value-Added Tax on Various Parts of the Cost}

In the calculation of the 9 water conservancy projects, the equipment and installation cost are calculated by the equipment value percentage method and the comprehensive tonnage index method, and the proportion of the total investment is relatively small, so it is not included in the scope of this analysis, and the key is to analyze changes in conservancy project, temporary construction, independent fee, prepaid expenses and total project cost affected by the policy of replacing Business Tax with Value-added Tax. Through the above calculation method, we can get the change range of the cost of various parts of the water conservancy project after replacing business tax with valueadded tax (Table 1).

(1) After the implementation of VAT of water conservancy project, the overall conservancy cost fluctuated slightly, showing a slight downward trend. The total project cost changed from $-1.32 \%$ to $1.12 \%$, and the average range of change is $-0.49 \%$.

(2) In the total investment of water conservancy projects, the proportion of the investment in conservancy project is the largest compared with other parts, which is converted from labor cost, material cost and mechanical use fees, and is decisive part of the project cost impact after the implementation of VAT. Materials and machinery make up a large proportion of conservancy project, and the main materials (steel, cement, etc.) can be deducted $17 \%$, secondary materials can be deducted $3 \%$, resulting in the part of the cost reduction. According to the calculation results, it shows that the change range of conservancy project is $1.35 \% \sim 1.43 \%$, and the average range of change is $-0.48 \%$.

(3) In the temporary construction, the proportion of labor and machinery is relatively large while the proportion of materials is small. Therefore, the cost of the temporary construction increases slightly as a whole, the change range of temporary construction is $-0.12 \% \sim 1.30 \%$, and the average range of change is $0.43 \%$.

(4) Independence fee is generally calculated based on the combined basis of I to IV, accounting for about $10 \%$ of the project investment, which is changed with the investment of construction and installation works[5]. Therefore, independence fee change does not play a decisive role, the range of the change is $-1.31 \% \sim 0.42 \%$, the average range of change is $-0.49 \%$. 
TABle I. The Scope Of Cost Change Of Various Parts Of Water Conservancy Project After Replacing The Business Tax With VALUE-ADDED TAX [\%]

\begin{tabular}{|c|c|c|c|c|c|c|c|c|c|}
\hline Project & & $\begin{array}{c}\text { I } \\
\text { conserv } \\
\text { ancy } \\
\text { project }\end{array}$ & $\begin{array}{c}\text { II } \\
\text { Electromechanical } \\
\text { Equipment and } \\
\text { installation }\end{array}$ & $\begin{array}{c}\text { III } \\
\text { metal structure } \\
\text { equipment and } \\
\text { installation }\end{array}$ & $\begin{array}{c}\text { IV } \\
\text { temporary } \\
\text { construction }\end{array}$ & $\begin{array}{c}V \\
\text { independ } \\
\text { ent fee }\end{array}$ & $\begin{array}{l}\text { Part I } \\
\text { to } V . \\
\text { total }\end{array}$ & $\begin{array}{l}\text { Reserve } \\
\text { fee }\end{array}$ & $\begin{array}{c}\text { total } \\
\text { project } \\
\text { cost }\end{array}$ \\
\hline \multirow{3}{*}{ hydro-junctions } & Item 1 & 0.52 & - & - & 0.41 & 0.42 & 0.52 & 0.52 & 0.51 \\
\hline & Item 2 & 1.43 & - & - & 0.38 & 0.20 & 1.13 & 1.13 & 1.12 \\
\hline & Item 3 & -0.77 & - & - & 0.02 & -1.31 & -0.91 & -0.91 & -0.89 \\
\hline \multirow{3}{*}{$\begin{array}{l}\text { water diversion } \\
\text { projects }\end{array}$} & Item 4 & -0.48 & - & - & 1.30 & -0.27 & -0.43 & -0.43 & -0.42 \\
\hline & Item 5 & -1.35 & - & - & -0.05 & -0.55 & -1.30 & -1.30 & -1.32 \\
\hline & Item 6 & -0.85 & - & - & -0.12 & -0.62 & -0.42 & -0.42 & -0.79 \\
\hline \multirow{3}{*}{ river projects } & Item 7 & -0.98 & - & - & 1. 05 & -0.66 & -0.85 & -0.85 & -0.88 \\
\hline & Item 8 & -0.45 & - & - & 0.28 & -0.30 & -0.42 & -0.42 & -0.41 \\
\hline & Item 9 & -1.35 & - & - & 0.56 & -1.29 & -1.30 & -1.30 & -1.31 \\
\hline average & & -0.48 & - & - & 0.43 & -0.49 & -0.44 & -0.44 & -0.49 \\
\hline
\end{tabular}

TABLE II. The Scope Of Cost Change Of The Proportion Of VArious EXPENSES In Construction ANd InSTALLATION Projects After REPLACING THE BUSINESS TAX WITH VALUE-ADDED TAX [\%]

\begin{tabular}{|c|c|c|c|c|c|c|c|c|}
\hline \multicolumn{2}{|c|}{ project } & \multirow{2}{*}{$\begin{array}{c}\text { Labor cost } \\
-0.03\end{array}$} & \multirow{2}{*}{$\begin{array}{c}\text { material cost } \\
-5.32\end{array}$} & \multirow{2}{*}{$\begin{array}{c}\begin{array}{c}\text { mechanical } \\
\text { use fee }\end{array} \\
-1.68\end{array}$} & \multirow{2}{*}{$\begin{array}{c}\begin{array}{c}\text { Labor material } \\
\text { machine } \\
\text { total }\end{array} \\
-7.03\end{array}$} & \multirow{2}{*}{$\begin{array}{c}\begin{array}{c}\text { Indirect } \\
\text { fee }\end{array} \\
0.35\end{array}$} & \multirow{2}{*}{$\begin{array}{l}\text { profit } \\
-0.11\end{array}$} & \multirow{2}{*}{$\begin{array}{l}\text { Taxes } \\
6.61\end{array}$} \\
\hline \multirow{3}{*}{ hydro-junctions } & Item 1 & & & & & & & \\
\hline & Item 2 & -0.02 & -5.18 & -1.66 & -6.86 & 0.34 & -0.11 & 6.60 \\
\hline & Item 3 & -0.06 & -5.62 & -1.81 & -7.49 & 0.38 & -0.13 & 6. 62 \\
\hline \multirow{3}{*}{$\begin{array}{l}\text { water diversion } \\
\text { projects }\end{array}$} & Item 4 & -0.13 & -5.20 & -1.70 & -7.03 & 0.37 & -0.12 & 6.60 \\
\hline & Item 5 & 0.04 & -5.68 & -1.87 & -7.51 & 0.44 & -0.12 & 6.68 \\
\hline & Item 6 & -0.05 & -5.62 & -1.72 & -7.39 & 0.43 & -0.12 & 6.61 \\
\hline \multirow{3}{*}{ river projects } & Item 7 & 0.01 & -5.66 & -1.82 & -7.47 & 0.36 & -0.12 & 6.60 \\
\hline & Item 8 & -0.05 & -5.42 & -1.68 & -7.15 & 0.36 & -0.11 & 6.60 \\
\hline & Item 9 & 0.01 & -5.65 & -1.84 & -7.48 & 0.32 & -0.12 & 6.68 \\
\hline \multicolumn{2}{|c|}{ average } & -0.03 & -5.48 & -1.75 & -7.27 & 0.37 & -0.12 & 6.62 \\
\hline
\end{tabular}

(5) The prepaid fee is calculated by percentage of the total investment from Part I to $\mathrm{V}$ according to the project scale, construction period and geological conditions. Therefore, the prepaid fee is equal to the change range of the total investment in Part I to $\mathrm{V}$ and the average change range, The change range is $-1.30 \% \sim 1.13 \%$, the average range of variation is $-0.44 \%$.

(6) The proportion of labor cost occupy a large, proportion of material cost and mechanical use fee occupy a smaller in water conservancy projects, the deduction is relatively small, it shows a small decline or a slight increase in the phenomenon. Material cost and mechanical use fee account for a large proportion, and materials cost can be deducted higher water projects, the downward trend is particularly evident. Based on the above, after the water conservancy industry decided to implement VAT, the cost of different water conservancy projects is not same.
IV. IMPACT OF REPLACING BUSINESS TAX WITH VALUEAdDED TAX ON THE COST OF EACH PART OF PROPORTION OF CONSTRUCTION AND INSTALLATION COSTS

Through the above calculation method, we can see the effect of various costs on the proportion of conservancy cost after replacing business tax with value-added tax(Table 2).

(1) After replacing business tax with value-added tax, the labor unit price has not been adjusted, so the labor cost accounted for a small proportion of the construction and installation projects. The deductible material cost was relatively large, with the deduction of $17 \%$ for the main materials (steel, cement, etc.). Secondary materials, commercial concrete deduction of $3 \%$. The purchase of sand, stone, soil material deduction of $2 \%$. Therefore, After replacing business tax with value-added tax, the material costs account for a significant drop in the proportion of the construction and installation works cost, the range of change is $-5.68 \% \sim-5.18 \%$. The range of mechanical use fee is $1.87 \% \sim-1.66 \%$. The total proportion of labor, materials, and 
machinery costs showed a declining trend with a range of $7.51 \% \sim-6.86 \%$.

(2) As the consolidated tax rate in water conservancy projects is adjusted from $3.48 \%, 3.41 \%$ and $3.28 \%$ to $11 \%$, calculation results show the proportion of tax on conservancy project increased to about $6.62 \%$. However, due to the deduction of various types of input tax on material fees and machine use fees, the tax-free price is reduced, and the tax base for taxation is correspondingly reduced. The total amount of taxes generated is still declining.

(3) The indirect fee is composed of stipulated fees and the enterprise management fee. After the implementation of VAT, the indirect fee will adds the previous city maintenance and construction tax, education surcharge, local education surcharge and management fee[4], the indirect fee rate increased accordingly, so the proportion of indirect costs accounting for construction and installation costs showed a slight increase in the trend.

\section{CONCLUSION}

After replacing business tax with value-added tax, the price of materials, fare standard, related quotas are adjusted accordingly, in the transitional phase through representative preliminary calculation results of water conservancy projects examples, draw the following conclusions:

(1) After replacing business tax with value-added tax, adopt according to the pricing rules of separation of price and tax. One increase and one decrease maintain the stability of water conservancy project cost. The calculation results are also in line with the forecast. Water conservancy project cost and corporate tax burden are mostly showing a certain downward trend.

(2)After replacing business tax with value-added tax, the labor cost basically remained unchanged, while the material cost and the mechanical use fee decreased more obviously.

(3) The main reason for the different decreasing scope is that the proportion of labor cost, material cost and mechanical use fee and the proportion of deductible are different from each other[6]. In the process of compiling water conservancy project cost in the future, each participant should control the project cost more effectively by appropriately increasing the rate of mechanical and so on utilization according to his own situation.

(4) After the implementation of the VAT, the corporate tax burden is reduced, the double taxation was avoided, and all parties involved are fully mobilized to help deepen the supply-side structural. The future development of the water industry has also played a very good role in promoting.

(5) In the process of compilation of water conservancy project cost, there are many factors affecting its change. The cost engineer should always keep learning the new laws, regulations and policies of the country and master the rule in order to achieve more effective control.

\section{REFERENCES}

[1] Yu-qiang Hu. water conservancy project " replace business tax with value-added tax " analysis [J/ OL]. Water conservancy planning and design, : 1-4

[2] Jing-Xin Liu. Impact of replace business tax with value-added tax on construction project cost and pricing system [R] . 2016.

[3] Notice of the Ministry of Finance and the State Administration of Taxation on Launching the Pilot Project of replacing business tax with value-added tax [J] . Revenue Collection, 2016, (04): 37-46.

[4] General Office of Ministry of Water Resources , cost adjustment method of replacing business tax with value-added tax on water conservancy project [R]. Beijing: General Office of Ministry of Water Resources, 2016.

[5] Jie Wu. " replace business tax with value-added tax " on the impact of water conservancy project cost $[\mathrm{J}]$. Jianghuai Water Resources Science and Technology, 2016, (04): 23-24.

[6] Ning Zhang. impact of replacing business tax with value-added tax on construction enterprises [D]. Shijiazhuang Railway University, 2014.

[7] Fund project: Henan Province, colleges and universities key scientific research projects $16 \mathrm{~A} 570009$ 